IFN Working Paper No. 845, 2010

\title{
Using Self-employment as Proxy for Entrepreneurship: Some Empirical Caveats
}

Carl Magnus Bjuggren, Dan Johansson and Mikael Stenkula 


\title{
Using Self-employment as Proxy for Entrepreneurship: Some Empirical Caveats*
}

\author{
Carl Magnus Bjuggren ${ }^{\S}$, Dan Johansson ${ }^{\ddagger}$ and Mikael Stenkula \\ June 14, 2010
}

\begin{abstract}
Research on entrepreneurship has received an increased amount of interest in recent years, with self-employment being used as the most common proxy for "entrepreneurship" in empirical studies. However, there are various ways of defining selfemployment, making it a somewhat dubious proxy. This may flaw the analysis, especially in cross-country studies, since the documentation of data often is insufficient and difficult to access due to language barriers. We present an analysis of Swedish self-employment data. We show that the measurement of self-employment has changed over time to noticeably affect the reported number of self-employed in the two major statistical sources on self-employment. The reported development of self-employment sometimes differs diametrically depending on source. Sweden is occasionally erroneously reported to show the largest increase in selfemployment in cross-country studies. Our study mimics the results of other country-specific analyses and we conclude that well-grounded conclusions require that the advantages and disadvantages of different statistical sources are recognized.
\end{abstract}

Keywords: Labor Force Survey, RAMS, self-employed, self-employment, entrepreneurship.

JEL Codes: C81; C82; L26; M13.

\begin{tabular}{|c|c|c|}
\hline $\begin{array}{l}{ }^{\S} \text { Linköping University and } \\
\text { Stockholm School of } \\
\text { Economics/EHFF }\end{array}$ & ${ }^{\ddagger}$ The Ratio Institute & $\begin{array}{l}\text { \#Research Institute of Industrial } \\
\text { Economics (IFN) }\end{array}$ \\
\hline P.O. Box 6501 & P.O. Box 3203 & P.O. Box 55665 \\
\hline SE - 11383 Stockholm & SE - 10364 Stockholm & SE - 10215 Stockholm \\
\hline Phone: +46-8-736 9273 & Phone: +46-8-441 5903 & Phone: +46-8-665 4500 \\
\hline $\begin{array}{l}\text { Fax: +46-8-441 } 5929 \\
\text { e-mail: carl- }\end{array}$ & $\begin{array}{l}\text { Fax: +46-8-4415929 } \\
\text { e-mail: dan.johansson@ @ratio.se }\end{array}$ & $\begin{array}{l}\text { Fax: +46-8-665 } 4599 \\
\text { e-mail: mikael.stenkula@ifn.se }\end{array}$ \\
\hline
\end{tabular}

\footnotetext{
* We are grateful for comments by Jan Andersson at Statistics Sweden on an earlier version of this article and by participants in a seminar at Ratio. Financial support from Sparbankernas Forskningsstiftelse (Bjuggren) and from Sparbanksstiftelsen Alfa (Johansson) is gratefully acknowledged. Stenkula gratefully acknowledges financial support from the Gustaf Douglas Research Program on Entrepreneurship at IFN and from the Jan Wallander and Tom Hedelius Research Foundation.
} 


\section{Introduction}

Entrepreneurship research holds a prominent role in business administration, economics, sociology and other academic disciplines. Both the public and policy makers share an interest in the research, as the results impact our understanding of the nature of the economy and the effects of various economic policies. Theoretically, entrepreneurship is an illusive concept. Empirically, a variety of quantitative proxies can be deployed to measure entrepreneurship. Self-employment is the most commonly used due to the accessibility of data, although it has been criticized for being too narrow, as all entrepreneurs are not self-employed, as well as too broad, since all self-employed are not entrepreneurs (e.g., Parker, 2004). Besides, there are different ways to define self-employment, each tainted by possible problems of data collection that could flaw the analysis. These difficulties often lack systematic documentation; even when such documentation exists, foreign researchers are usually hindered to take part of it due to language barriers. ${ }^{1}$

The purpose of this paper is to compare how differences and changes in the measurement of self-employment in the two statistical sources documenting the total number of selfemployed in Sweden affect the reported number. This requires in turn that the measure of self-employment for each of the two statistical sources be systematically documented. While earlier papers have discussed general problems with measuring self-employment (Blanchflower, 2000; OECD, 1992, 2000; van Stel, 2003) or discussed specific countries such as the United States (Boden and Nucci, 1997; Bregger, 1996), Canada (Macredie, 1985) or the United Kingdom (Casey and Creigh, 1988; Creigh et al., 1986; Hakim, 1988; Mason et al., 2009; Meager, 1991), Swedish self-employment statistics have never been subjected to indepth analysis. Such an investigation is of general interest since Swedish data are commonly used in cross-country analysis. It also serves as an unusually good example of the importance of recognizing the caveats inherent in the self-employment statistics that underlie research and policy decisions, since Sweden is sometimes mistakenly reported to have enjoyed the largest increase in self-employment in the mid-1980s in cross-country analyses. We show this to be a statistical fallacy caused by a change in the measurement of self-employed. The measurement of self-employment undergoes vast changes, creating pitfalls for analyses even if the same source is used. The two statistical sources also offer contradictory results regarding the level and the changes of self-employment.

\footnotetext{
${ }^{1}$ A database called COMPENDIA has been established to harmonize international self-employment data (van Stel, 2005). Still, many problems prevail.
} 


\section{The Concept of "Self-employment"}

From a theoretical point of view, entrepreneurship is a multidimensional concept. Definitions often overlap and conflict with one another, which easily can cause confusion among scholars and policy makers (e.g., Acs and Szerb, 2009; Iversen et al., 2008). Parker (2004, page 5), claims that defining entrepreneurship is "one of the most difficult and intractable tasks faced by researchers working in the field".

However, some sort of proxy must be used in empirical studies. Self-employment is the most frequently used proxy for entrepreneurship in literature that addresses a number of issues, such as the level of entrepreneurship across countries (e.g., Acs et al., 1994; Blanchflower, 2004; OECD, 1998), the link between entrepreneurship and growth (e.g., Carree et al., 2002, 2007), and the relationship between taxation and entrepreneurship (e.g., Bruce, 2002; Bruce and Mohsin, 2006; Robson and Wren, 1999). Moreover, labor economists regularly equate entrepreneurship with the rate of self-employment in applied works (Parker, 2004). The foremost reason to use self-employment as a proxy for entrepreneurship is a function of practicality: all developed countries report data on self-employment, facilitating analyses across countries and over time.

Acs et al. (1994) is often cited as the first international study to use the rate of selfemployment as a proxy for entrepreneurship, ${ }^{2}$ yet several other proxies can be applied depending on the question at hand. For instance, if entrepreneurship and job creation form the center of an analysis, the primary focus should maybe be placed on high-growth firms. ${ }^{3}$ If, on the other hand, the innovative aspect of entrepreneurship is being emphasized, a preferable proxy would involve innovative firms rather than self-employment or firms of a particular size. ${ }^{4}$ Other proxies include the number of new firms (births), the number of births and exits (turbulence), survival and growth rates of new and established firms, and the share of SMEs. Researchers have also constructed broader measures of entrepreneurship based on several underlying variables, for instance the Global Entrepreneurship Index, GEINDEX (Acs and Szerb, 2009).

\footnotetext{
${ }^{2}$ According to Davis (2008), early $18^{\text {th }}$ century French economist Richard Cantillon loosely defined entrepreneurship as self-employment of any sort, referring to a risk-taking person who bought goods for a certain price and sold them for an uncertain price in the future for an expected profit.

${ }^{3}$ New evidence indicates that only a small share of all firms, sometimes called gazelles, generate most of new net jobs (see Henrekson and Johansson 2010 for a survey).

${ }^{4}$ Acs (2008) introduces the concept of high-impact entrepreneurship, referring to those entrepreneurial activities that commercialize key innovations or create disruptive breakthroughs. However, a typical self-employed is not characterized by high-impact entrepreneurship, and high-impact entrepreneurship is not necessarily performed by self-employed. See Henrekson and Stenkula (2010) for a further discussion concerning high-impact entrepreneurship and public policy.
} 
Studies on self-employment itself, unrelated to the concept of entrepreneurship, are also abundant. Still, whether the rate of self-employment is decreasing, increasing or U-shaped over time is under dispute, and an issue that underlines the problem with self-employment data (e.g., Blanchflower, 2000; Bögenhold and Staber, 1991, 1993; Katz, 1990; Nunziata, 2009; OECD, 2000).

Comparing and analyzing self-employment data is difficult. First, no generally accepted definition of self-employment exists; it remains unclear, for example, whether owners of incorporated businesses should be included in the definition or not. Second, there may be differences in data coverage, leading some industries to be underrepresented-and some to be excluded altogether. Third, data may be collected in different ways, from surveys or registers. Fourth, the way of classifying people may differ. In interview surveys, the classification into the appropriate group can be done by either the interviewer or by the respondent.

Self-employed can be broadly defined as a residual, i.e., as occupied persons who are not employees (e.g., OECD, 1992). A more distinct (economic) definition can be grounded in the economic risk and type of authority involved (ILO, 1993). ${ }^{5}$ An employee works for somebody else-an employer. A self-employed person is someone who independently operates his/her business, without being subjected to the control of a supervisor. He/she does not have an employer, and is fully responsible for making the operational decisions to ensure the wellbeing and survival of the organizational unit. Remuneration springs directly from the profit or revenues generated by this very organizational unit.

In general, a person operating his/her business as a sole proprietorship, partnership or limited partnership is classified as self-employed (unincorporated self-employed), whereas passive owners and employees are not. Owners/managers of incorporated businesses (OMIBs) who are actively engaged in their businesses are often classified as employees for taxation purposes, as they receive wages as part of their compensation. Taxation registers are often used to classify people into employed and self-employed (OECD, 2000).

When included in the definition, OMIBs constitute a significant share of all selfemployed, and seem to have increased faster than unincorporated self-employed during the last decades (van Stel, 2008). In the US, OMIBs accounted for almost one third of all selfemployed in 1998 (OECD, 2000). Barring the US, Australia and Japan — which treat OMIBs as employees - most national labor force surveys classify OMIBs as self-employed (OECD,

\footnotetext{
${ }^{5}$ A sociological definition of self-employed can include ownership of the means of production and autonomy in the work process (see Dale 1986 for further discussion).
} 
2000). ${ }^{6}$ This somewhat ambivalent recognition of OMIBs as self-employed can cause difficulties when making international comparisons (e.g., van Stel, 2005).

Figure $1 \mathrm{a}-\mathrm{b}$ shows the annual percentage change in the number of self-employed over time for a selected group of nine OECD countries. They are the only countries in the OECD labor force statistics database to offer continuous data on self-employment during the 45-year period of $1963-2007 .^{7}$ Strikingly, the Swedish data take a leap in 1987, which many studies interpret as a true increase in the level of self-employment (see Blanchflower, 2000, for example). ${ }^{8}$ Other deviations also emerge, such as the United States in 1967, Belgium in 1970, Poland in 1978 and Norway in 2006. These variations, however, are relatively small in comparison. ${ }^{9}$ The large deviation shown by Sweden provides a reason to further investigate Swedish self-employment statistics and try to establish the underlying cause.

\footnotetext{
${ }^{6}$ The data from the national labor force surveys are collected and presented in OECD labor force statistics. Data about self-employment are also reported in OECD National Account. According to OECD, only unincorporated self-employed persons are supposed to be treated as self-employed in the National Account, but according to van Stel and Carree (2004), the definition differs between countries.

${ }^{7}$ International data on self-employment is reported by, e.g., ILO, Eurostat and OECD. OECD's labor force statistics database contains the longest time series. 1963 is the first year for which Swedish data are available.

${ }^{8}$ These researchers recognize the problem of comparability of self-employment data across countries and over time. The cases exemplify the problem with insufficient documentation and language barriers when using international data based on different national sources.

${ }^{9}$ The drop in the number of self-employment in 1967 in the US refers to the exclusion of OMIBs (e.g., Bregger, 1996) and serves as an example of statistical pitfalls.
} 


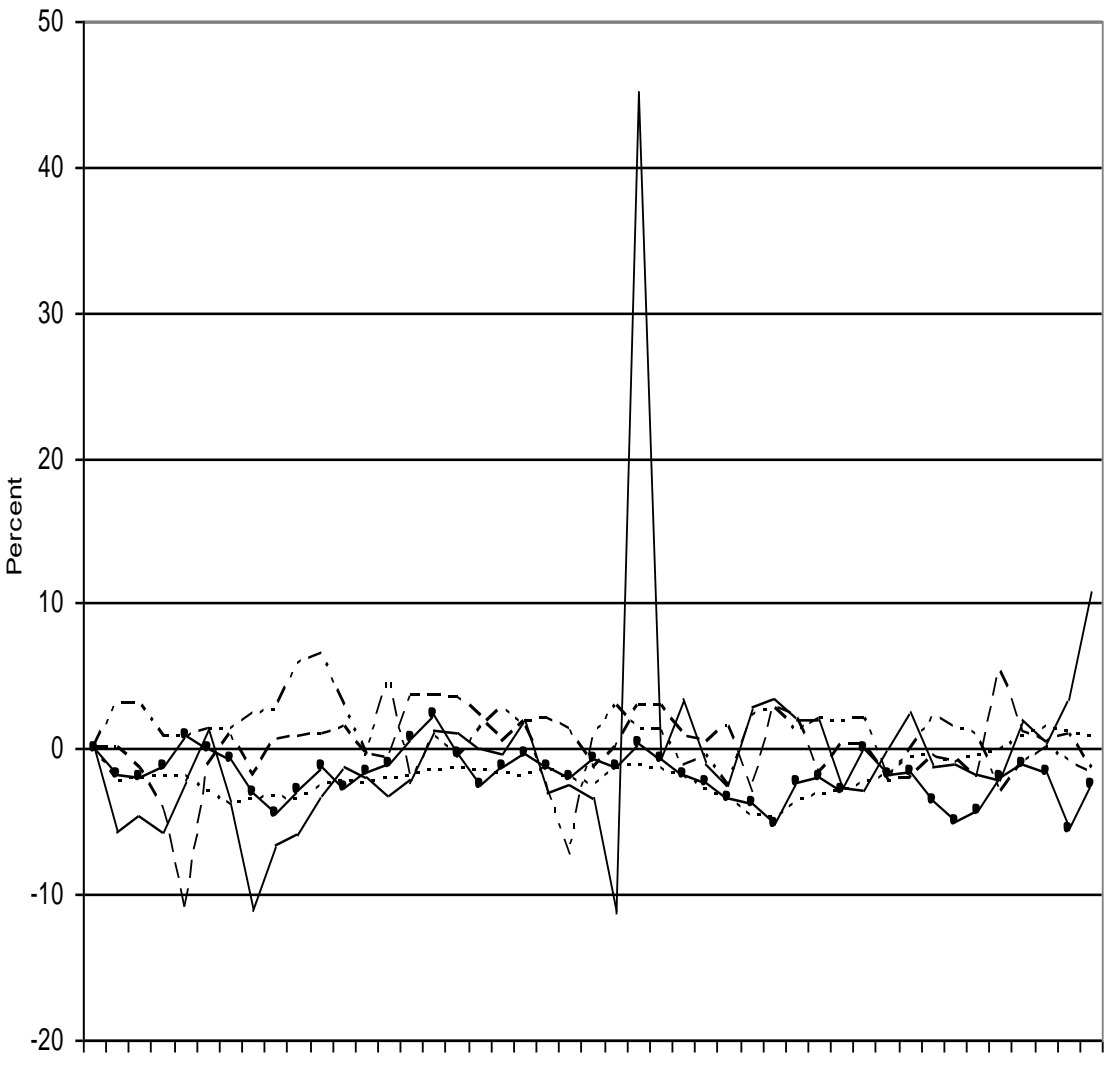

196319661969197219751978198119841987199019931996199920022005

Year

\begin{tabular}{|ll|}
\hline Sweden & --- - United States \\
- J Japan & $-\cdots \cdot$. F France \\
\hline
\end{tabular}

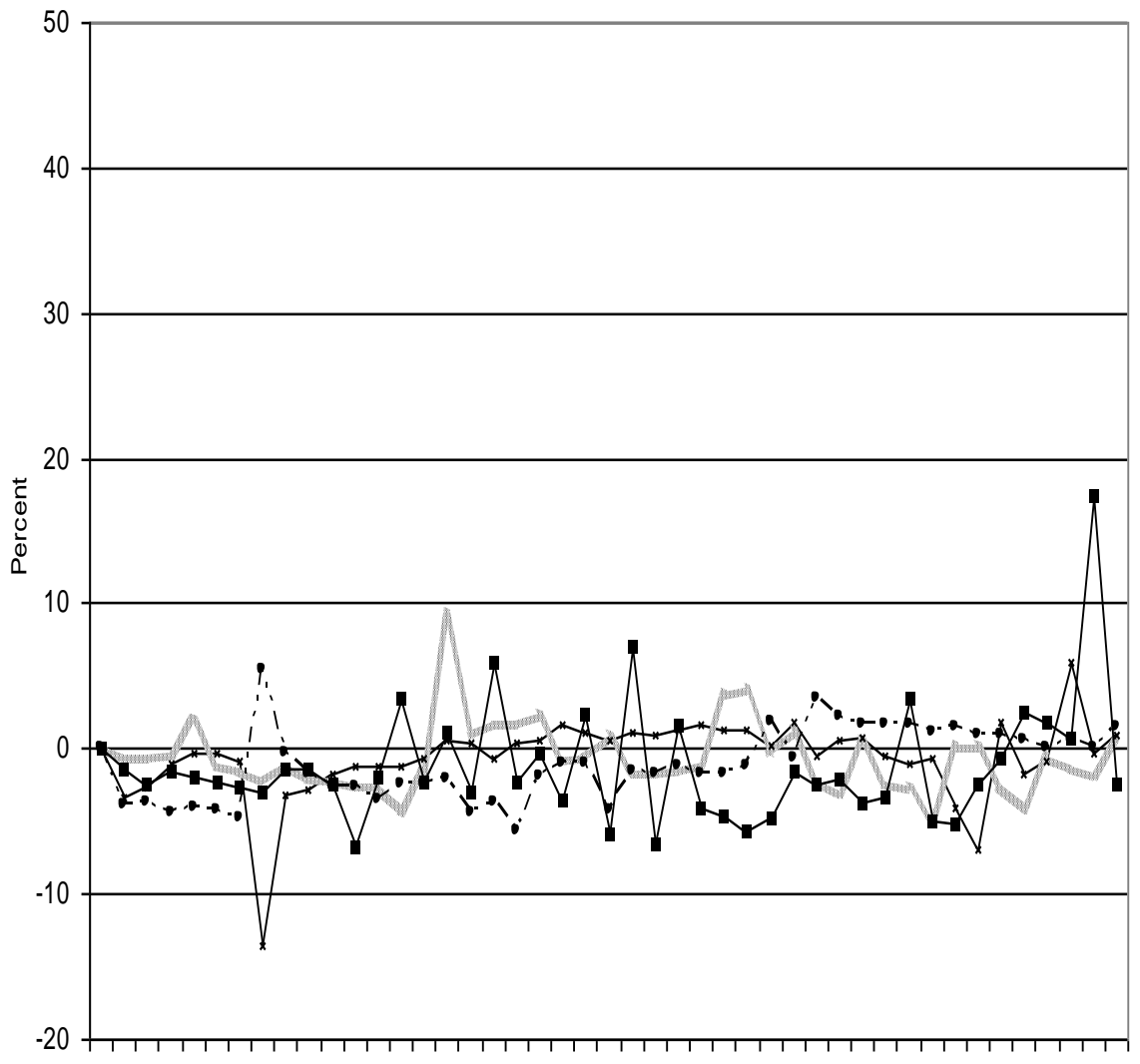

196319661969197219751978198119841987199019931996199920022005

Year

Figure 1a-b. Annual percentage change in the number of self-employment Note: Data for Norway 1971 is imputed.

Source: OECD Stats Extracts, ALFS Summary Tables. 


\section{The Swedish data}

Statistics Sweden reports data on the number of self-employed in two official sources, LFS (Labor Force Survey) and RAMS (Labor Statistics Based on Administrative Sources). ${ }^{10}$ Both sources are used in empirical studies. LFS underlies the OECD statistics in Figure 1 and RAMS is often used in research, in existing databases such as LISA ${ }^{11}$, and as a source for the Sweden Statistics micro data online access MONA (e.g., Johansson et al., 2009). Other labororiented statistical sources, such as KS (short-term employment statistics), do not report data about self-employment. ${ }^{12}$

The LFS is an individual-based survey with the purpose of depicting actual employment conditions and providing information about the development of the labor market. It is a monthly survey that encompasses about 20,000 people (Statistics Sweden, 2006a, page 17) who are asked in telephone interviews about their current employment situation (Statistics Sweden, 2005). The sample has changed somewhat over time, but neither the general method nor definition has changed significantly in the 25 years since the initial LFS survey in 1963 (Statistics Sweden, 2002, chapter 4). The major change in the LFS's self-employment data concerns the inclusion of OMIBs after 1986 (Statistics Sweden, 1992, page 15). When OMIBs were included, the number of self-employed (including the agricultural sector) soared 50 percent. This change in the statistics explains the spike in the Swedish self-employment level in Figure 1. In 1986, the number of self-employed was measured according to both the old and the new definitions, one including OMIBs and one excluding OMIBs. The LFS has not published any data that separate the numbers in a similar manner since 1986. Any use of the Swedish LFS that describes the development of self-employment during the years 1986 and 1987 is therefore problematic in this regard. ${ }^{13}$

RAMS, on the other hand, comprises the entire Swedish population. Its statistics are compiled from employees' income statements and the income-tax returns of self-employed. The purpose of RAMS is to document labor market development, from the perspective of

\footnotetext{
${ }^{10}$ In Swedish, Labor Force Survey is called Arbetskraftsundersökningarna (AKU). RAMS stands for Registerbaserad arbetsmarknadsstatistik. LFS is a commonly accepted abbreviation for this form of survey and we choose to use this English abbreviation. There is no equivalent English abbreviation for RAMS so we will use the original Swedish abbreviation.

${ }^{11}$ LISA is the Swedish acronym for a longitudinal integration database for health insurance and labor market studies.

${ }^{12} \mathrm{KS}$ stands for Kortperiodisk sysselsättningsstatistik.

${ }^{13}$ It is possible to contract Statistics Sweden (for a fee) to extract OMIBs from the self-employment data from 1999 onwards. Even Finland started to include OMIBs in their definition of self-employed this year (van Stel, 2003). It is notably, that the change in the US in 1967 went in the other direction, excluding OMIBs, cf. the previous discussion. Also notably is that un-paid co-workers are counted as self-employed in the Swedish LFS (8,100 people in 2006). This category was published separately in the regular tables until 2004, but subsequently the separation of un-paid co-workers is only available in supplementary tables.
} 
both population and the business world. Yearly data have been made available as of 1985, based on reigning conditions in the month of November. In order to be classified as selfemployed, an individual has to actively run his/her business, meaning that the business requires at least one third of the time normally spent in full-time employment. Regarding people who draw income from both the self-owned corporation and from an additional employer, the principle of the highest wage-sum in November is applied (Hanaeus et al., 2006, page 6; Statistics Sweden, 2006b, page 11; Statistics Sweden, 2007a, page 34), implying that people are classified as employed or self-employed according to their highest income.

OMIBs were first included and published in RAMS in 1989, at which point they amounted to about 110,000. A difficulty concerning the definition of self-employed in RAMS is that people have to demonstrate a surplus from their business in order to qualify as selfemployed. In 2004, however, this profit criterion was abolished. The previous year, 2003, Statistics Sweden published statistics according to both the new and the old method, including and excluding the profit requirement. A comparison reveals that the new method increased self-employment by about 64,840 individuals that year (Statistics Sweden, 2008).

Changes promoting more suitable definitions and improved methods over time ought to be of great interest and concern for scholars and policy makers. At the same time, a change in the definition of self-employment complicates analyses over a longer period of time. Ever since the Swedish LFS altered its definitions in 1987 by including OMIBs, it is no longer possible to obtain data on self-employment that excludes OMIBs, unless one specifically orders the material from Statistics Sweden. Even then, the first available year, excluding OMIBs, is 1999. Moreover, data including OMIBs before 1986/87 are not available. Thus, what remains are two series, the first from 1963 to 1986 (can also be extracted from 1999 to 2007) and the second from 1986 to 2007. This renders the identification of long-term trends in levels of selfemployment more difficult and aggravates econometric analyses. Even though it is possible to extract detailed information from RAMS, the information may very well be insufficient, as RAMS began in 1985 and does not include OMIBs until 1989. Removal of the profit requirement in 2003 further complicates an analysis of self-employment over time.

EIM Business and Policy Research in the Netherlands has created a database, COMPENDIA (COMParative ENtrepreneurship Data for International Analysis), with international comparable self-employment data based on OECD labor force statistics. In order to make the OECD data comparable, the number of OMIBs is estimated when missing. The total number of self-employed in Sweden before 1987 is approximated by assuming that the 
share of OMIBs is the same as in $1986 / 1987 .{ }^{14}$ This will erase the spike in the data in $1986 / 1987$, but it is a rather crude way to estimate a consistent and comparable measure of self-employment, as the share of OMIBs probably changed over the period. Despite this, COMPENDIA's harmonized dataset is preferable to the unrevised dataset from OECD, which does not take the change in definitions into account; see, for example, Thurik et al. (2008) for a recent example.

\section{Comparison between LFS and RAMS}

Although the COMPENDIA database is an effort to make self-employment data internationally comparable, the national self-employment data in itself can be problematic, rendering such an attempt difficult in practice. As an illustration, Figures 2 and 3 portray the annual level and change in self-employment according to LFS and to RAMS for the timeperiod 1989-2006. 1989 is the first year self-employment, including OMIBs, is published by both LFS and RAMS. It is not possible to conduct a similar series excluding OMIBs.

There is a considerable difference in the reported number of self-employed. In the middle of the 1990s, the difference is at its maximum of 155,000 people (Figure 2). The LFS figures are almost 50 percent higher during this period. Taking into account that the LFS includes unpaid family members, the disparity appears nevertheless rather substantial. Moreover, the changes in self-employment level take opposite directions at certain points. This becomes most evident in the beginning of the 1990s, when the number of self-employed first drops (1990-1991) and then rises (1992-1993) according to LFS, whereas it first rises and then profoundly drops according to RAMS (Figure 3).

\footnotetext{
${ }^{14}$ In Sweden, the number of OMIBs increased the self-employed with about 67 per cent in 1987, according to COMPENIDA's calculations referring to the non-agricultural self-employed, i.e. the OMIBs share was about 40 per cent. Hence, the number of self-employed has been increased with 67 per cent before 1987. Corrections for other countries are usually done in the same way in COMPENDIA.
} 


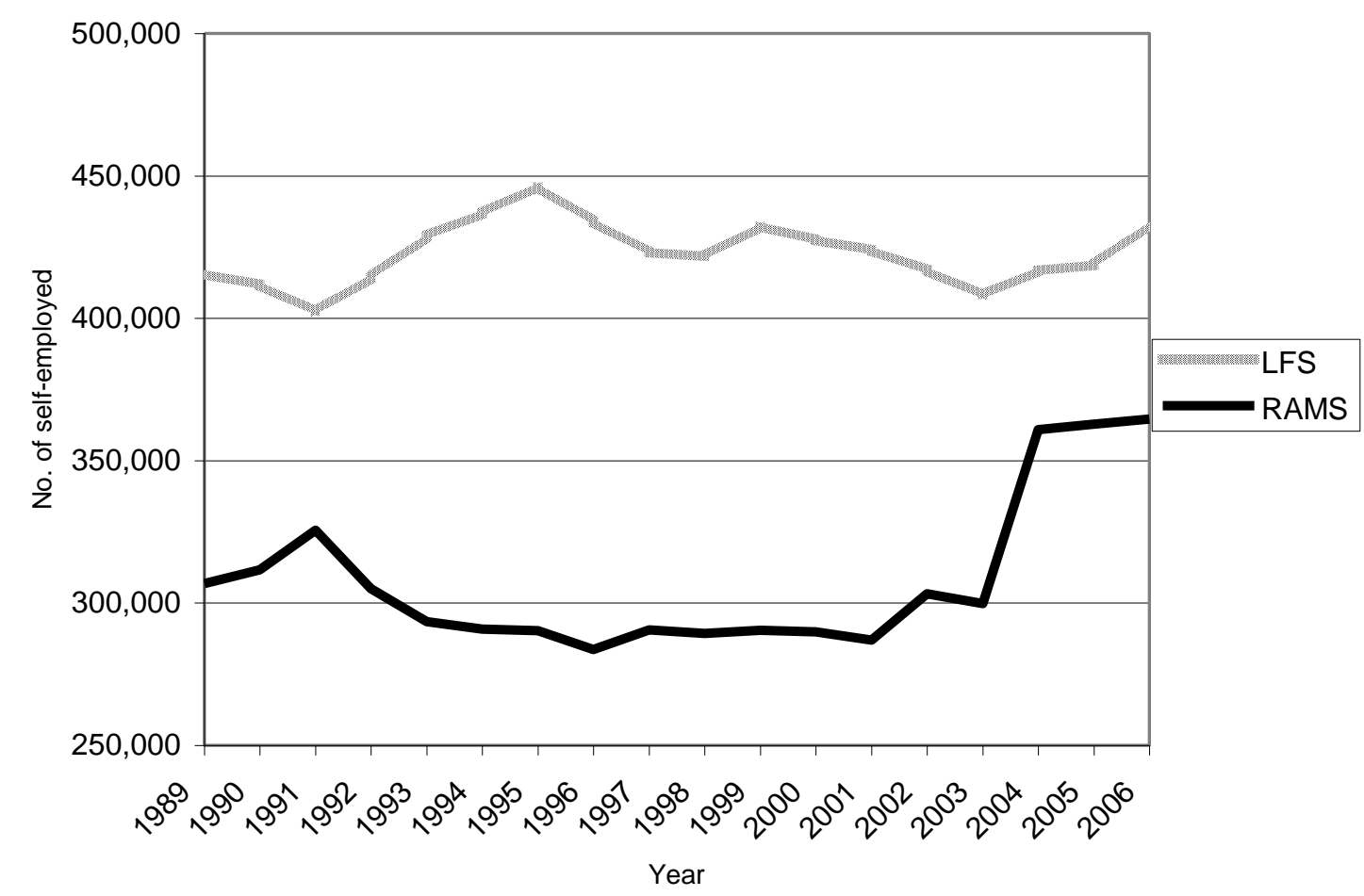

Figure 2. Self-employment according to LFS and RAMS between 1989 and 2006

Note: The figure illustrates total self-employment in the economy, including all industries and companies. Source: Statistics Sweden.

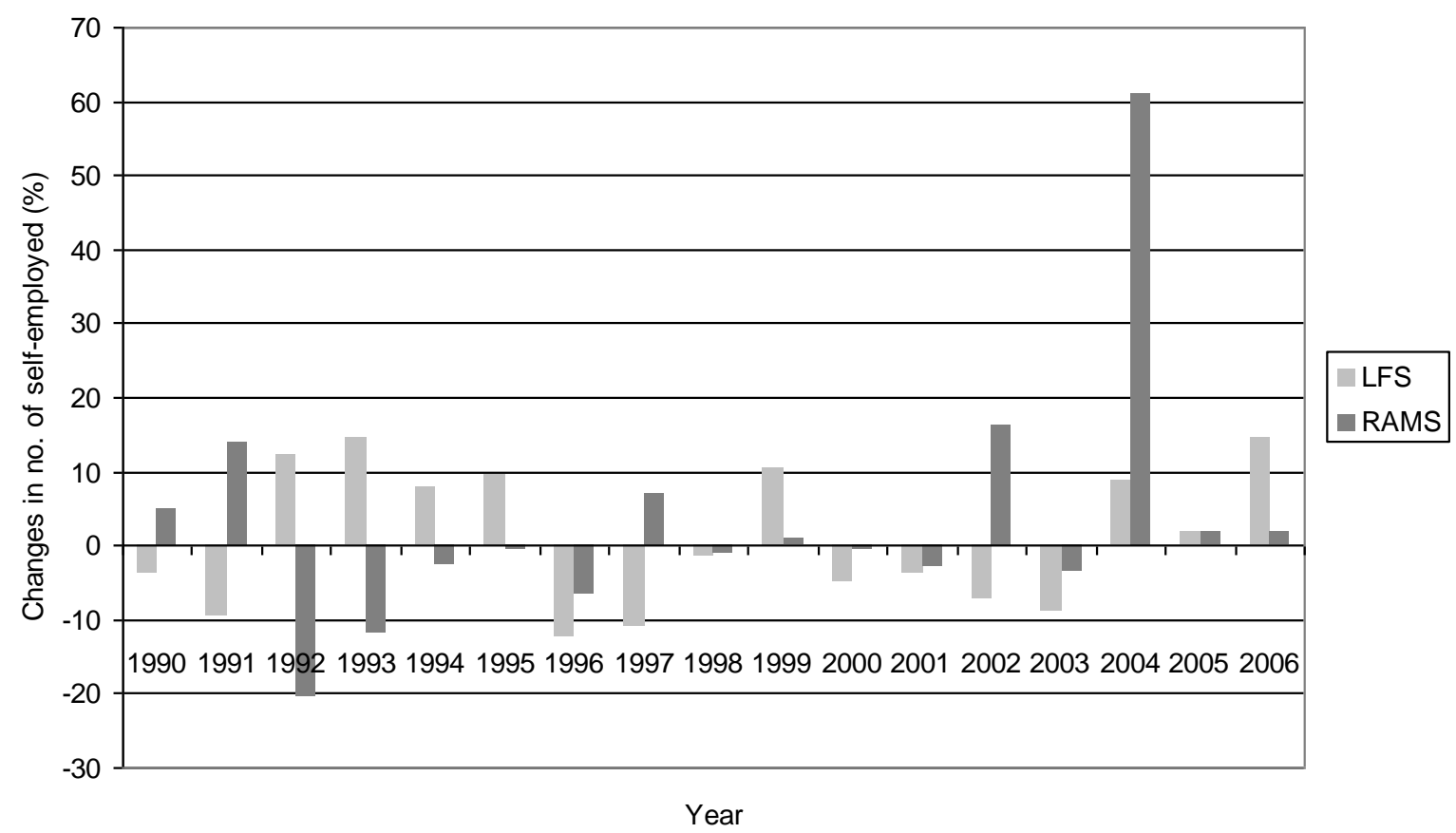

Figure 3. Annual change in self-employment according to LFS and RAMS between 1990 and 2006

Note: The figure illustrates total self-employment in the economy, including all industries and companies. Source: Statistics Sweden. 
Since the two sources use different measurement methods, a certain discrepancy is inevitable. The difference is thus partly dependent on LFS being a survey, based on a sample of the population, whilst RAMS is a register, based on the total population. As LFS is a survey, the estimations made by LFS suffer from sampling error, which may in turn explain some of the differences between RAMS and LFS. Statistics Sweden continuously publishes measures of uncertainty for the LFS, based on a 95 percent confidence interval. In 2006, the measure of uncertainty for self-employed was 11,900 (Statistics Sweden, 2007b). This ought to be considered a small number relative to the differences depicted in Figure 2 and cannot explain the discrepancy between the two sources. ${ }^{15}$

One probable reason in explaining some of the differences between RAMS and LFS is that information in LFS is based on people's statements, whereas RAMS is grounded in activity reported to the tax authority. This can lead to differences because there might be a general tendency amongst individuals to consider and identify themselves as self-employed, although register-based statistics would not identify them in that way (Hanaeus et al., 2006). A pertinent example arises when a person has two occupations and two incomes, from both a self-owned company and an employer. Because the statistics do not allow a person to be classified as both an employee and self-employed, there must be a method for determining when to be classified as one or the other. Direct rules govern this distinction in RAMS, namely the principle of highest wage-sum in November (see discussion above). In LFS the respondent decides how to state their main occupation, according to their own criteria.

There are other possible explanations for the differences between RAMS and LFS. At the beginning of the 1990s Sweden underwent one of the most serious economic crises in modern history. It is plausible that many self-employed incurred losses during this period, implying that they were excluded from the RAMS-statistics whilst still present in the LFS-statistics. Parallel to this development, it is possible that a rising number of people during the same time period decided to become self-employed as a response to a lack of other job opportunities. This type of necessity entrepreneurship is frequent in recessions. ${ }^{16}$ It is also possible that a large portion of this necessity entrepreneurship was initially run at a loss, which resulted in exclusion from RAMS but inclusion in LFS. This occurrence probably stands for a substantial part of the discrepancy seen in Figure 3 between 1992 and 1994. As mentioned above, the

\footnotetext{
${ }^{15}$ A slight discrepancy may also arise as LFS is based on an annual average but RAMS is based on the situation in November. The number of self-employed persons fluctuates over the year and there is nothing that a priori says that the situation in November should be equal to the annual average. This difference is, however, rather small and will not influence the main results presented here.

${ }^{16}$ See, e.g., Bosma et al. (2008) for a discussion of necessity entrepreneurship and other types of entrepreneurship.
} 
number of self-employed also deviated in 1990-1991, but in the opposite direction: it increased in RAMS but decreased in LFS. In 1990, the Swedish economy was booming, resulting in rising demand for employees and high wage increases. This may have led some self-employed (in particular those with bad outcomes despite a prospering economy), to switch to regular employment at the same time as the share of self-employed who were making a profit increased. Hence, in booming economies the self-employment level may increase in RAMS (before 2003) but decrease in LFS; in recessions, it is the other way around. After RAMS was redefined in 2003 and the profit requirement abandoned, the dissimilarity between the LFS and RAMS drastically decreases (figure 2). In 2006, LFS reported about 50,000 persons or roughly 12 percent more self-employed than RAMS. In 1989 , before the crises of the 1990s, the difference was about 110,000, or about 35 percent.

Nonetheless, disregarding the classification of self-employment, the comparability between RAMS and LFS is considered rather good when it comes to employment definitions (Statistics Sweden, 2006b, p. 13). Table 1 summarizes the measurement of self-employed in LFS and in RAMS.

Table 1. Statistical source and the measurement of self-employment

\begin{tabular}{lllll}
\hline \hline $\begin{array}{l}\text { Statistical } \\
\text { source }\end{array}$ & $\begin{array}{l}\text { Time } \\
\text { period }\end{array}$ & Survey/Register & Including OMIBs & $\begin{array}{l}\text { Excluding } \\
\text { non-profitable } \\
\text { companies }\end{array}$ \\
\hline LFS & $1963-1986$ & Survey & No & No \\
LFS & $1987-$ & Survey & Yes & No \\
RAMS & $1985-1988$ & Register & No & Yes \\
RAMS & $1989-2003$ & Register & Yes & Yes \\
RAMS & $2004-$ & Register & Yes & No \\
\hline
\end{tabular}

\section{Conclusion and Discussion}

The rate of self-employment is often used as a proxy for the entrepreneurial activity in an economy. The case of Sweden, with its two major sources of self-employment data-Labor Force Survey (LFS) and RAMS — can be used to illustrate potential problems with selfemployment statistics. Many cross-country analyses that use OECD self-employment data as a proxy for entrepreneurship see a leap in Swedish entrepreneurial activity in 1987. This discrepancy is shown to be a statistical fallacy due to a change in the definition of selfemployment in the Swedish LFS, which serves as the basis for the OECD labor force statistics. Prior to 1987, OMIBs (owners/managers of incorporated businesses) were not treated as self-employed but as employees. It appears as though many scholars have not paid 
this leap due attention, perhaps because of a lack of documentation concerning the statistics and language barriers.

When comparing LFS with the second data source covering self-employment, RAMS, we found other striking differences. First, the sources report large differences in the absolute number of self-employed. Second, the changes in self-employment level occasionally take opposite directions; in a specific year, self-employment may very well increase according to LFS while it decreases according to RAMS. We show that these divergences emerge because the two statistical sources measure self-employment differently. Moreover, the way selfemployment is measured has changed over time in both LFS and RAMS. The most significant difference between the sources is that RAMS excludes self-employed businesses incurring a loss before 2004. After this change, the differences between LFS and RAMS have dramatically lessened.

Our study complements other country-specific analyses discussing caveats with selfemployment statistics. Due to the exceptionally large spike found in Swedish selfemployment statistics, Sweden serves as an unusually good example of obstacles researchers may encounter when analyzing self-employment data. Our systematic analysis of selfemployment statistics highlights some of the problems one should be aware of when using easily available data and will hopefully help improve research on entrepreneurship using selfemployment as a proxy.

\section{References}

Acs, Z.J. (2008) 'Foundations of High Impact Entrepreneurship', Foundations and Trends in Entrepreneurship 4(6): 535-620.

Acs, Z.J., Audretsch, D.i B. and Evans, D. S. (1994) 'Why Does the Self-employment Rate Vary across Countries and Over Time?', Discussion Paper No. 871, CEPR, London. Acs, Z.J. and Szerb, L. (2009) 'The Global Entrepreneurship Index (GEINDEX)',

Foundations and Trends in Entrepreneurship 5(5): 341-435.

Blanchflower, D.G. (2000) 'Self-employment in OECD Countries', Labour Economics 7(5): 471-505.

Blanchflower, D.G. (2004) 'Self-employment: More May Not Be Better', Swedish Economic Policy Review 11(2): 15-74.

Boden, R.J. and Nucci, A.R. (1997) 'Counting the Self-Employed Using Household and Business Sample Data', Small Business Economics 9(5): 427-436.

Bögenhold, D. and Staber, U. (1991) 'The Decline and Rise of Self-Employment' Work, Employment \& Society 5(2): 223-239.

Bögenhold, D. and Staber, U. (1993) 'Self-employment: A Study of Seventeen OECD Countries’ Industrial Relations Journal 24(2): 126-137. 
Bosma, N., Jones, K., Autio, E., and Levie, J. (2008) 'Global Entrepreneurship Monitor: 2007 Executive Report', Wellesley: Babson College and London: London Business School.

Bregger, J.E. (1996) 'Measuring Self-employment in the United States', Monthly Labor Review Jan/Feb: 3-9.

Bruce, D. (2002) 'Taxes and Entrepreneurial Endurance: Evidence from the Self-Employed' National Tax Journal 55(1): 5-24.

Bruce, D. and Mohsin, M. (2006) 'Tax Policy and Entrepreneurship: New Time-series Evidence' Small Business Economics 26(5): 409-425.

Carree, M.A., van Stel, A.J., Thurik, R.A. and Wennekers, S. (2002) 'Economic Development and Business Ownership: An Analysis Using Data of 23 OECD Countries in the Period 1976-1996' Small Business Economics 19(3): 271-290.

Carree, M., van Stel, A., Thurik, R., Wennekers, S. (2007) 'The Relationship between Economic Development and Business Ownership Revisited', Entrepreneurship \& Regional Development 19(3): 281-291.

Casey, B. and Creigh, S. (1988) 'Self-employment in Great Britain: Its Definition in the Labour Force Survey, in Tax and Social Security Law and in Labour Law', Employment, Work and Society 2(3): 381-391.

Creigh, S., Roberts, C., Gorman, A., and Sawyer, P. (1986) 'Self-employment in Great Britain: Results from the Labour Force Surveys 1981-1984', Employment Gazette 94(6): 183-194.

Dale, A. (1986) 'Social-class and the Self-employed', Sociology 20(3): 430-434.

Davis, T. (2008) 'Understanding Entrepreneurship: Developing Indicators for International Comparisons and Assessments', in Congregado, Emilio (ed.) Measuring Entrepreneurship, 39-64. New York: Springer.

Hakim, C. (1988) 'Self-Employment in Britain: Recent Trends and Current Issues', Work Employment Society 2(3): 421-450.

Hanaeus, C-G., Håkansson, M., and Voss, L. (2006) 'Ny källa till företagarpopulationen i den registerbaserade arbetsmarknadsstatistiken (RAMS)', Statistiska Centralbyrån, Rapport SRU, 06-11-21.

Henrekson, M. and Johansson, D. (2010) 'Gazelles as Job Creators - A Survey and Interpretation of the Evidence', Small Business Economics, forthcoming.

Henrekson, M. and Stenkula, M. (2010) 'Entrepreneurship and Public Policy', in Acs, Z.J. and Audretsch, D.B. (eds.) Handbook of Entrepreneurship Research. New York: Springer.

ILO (1993) 'Resolution concerning the International Classification of Status in Employment (ICSE)', URL (consulted October, 2009): http://www.ilo.org/wcmsp5/groups/public/---dgreports/---integration/--stat/documents/normativeinstrument/wcms_087562.pdf

Iversen, J., Jørgensen, R. and Malchow-Møller, N. (2008) 'Defining and Measuring Entrepreneurship', Foundations and Trends in Entrepreneurship 4(1): 1-63.

Johansson, D., Sjögren, H. and Bjuggren, C-M. (2009) 'Family Business, Employment and GDP', Working Paper no. 145, Ratio.

Katz, J. (1990) 'Longitudinal Analysis of Self-employment Follow-through', Entrepreneurship and Regional Development 2(1): 15-25.

Macredie, I.D. (1985) 'Self-employment in Canada: An Overview', The Labour Force February: 83-89.

Mason, C., Pinch, S. and Storey, A. (2009) 'Self-employment in a British City: An Analysis of Household Survey Data', International Small Business Journal 10(1): 27-43.

Meager, N. (1991) 'Self-employment in the United Kingdom', Institute of Manpower Studies Report No. 205, University of Sussex. 
Nunziata, L. (2009) 'Aggregate Self-Employment Patterns, Working paper presented at the EALE, ASSET and AIEL Conferences, 2008.

OECD (1992) 'Recent Developments in Self-Employment', Chapter 4 in OECD Employment Outlook, 155-94. Paris: OECD.

OECD (1998) Fostering Entrepreneurship. Directorate for Employment, Labor and Social Affairs. Paris: OECD.

OECD (2000) 'The Partial Renaissance of Self-employment' Chapter 5 in OECD Employment Outlook, 155-198. Paris: OECD.

OECD. Stats Extracts. http://stats.oecd.org/WBOS/index.aspx, 2008-11-11.

Parker, S.C. (2004) The Economics of Self-employment and Entrepreneurship. Cambridge, UK: Cambridge University Press.

Robson, M.T. and Wren, C. (1999) 'Marginal and Average Tax Rates and the Incentive for Self-Employment' Southern Economic Journal 65(4): 757-773.

Statistics Sweden (1992) Förändringar i arbetskraftsundersökningarna. Bakgrundsfakta till arbetsmarknadsstatistiken, 1992:1.

Statistics Sweden (2002) Arbetskraftsundersökningarna 2002. AM 0401.

Statistics Sweden (2005) AKU Nyklassblankett URL (consulted month, year): http://www.scb.se/statistik/AM/AM0401/Nyklassblankett_Tryck_April05.pdf, 2005-04-01.

Statistics Sweden (2006a) Arbetskraftsundersökningarna 2006. AM 12 SM 0701.

Statistics Sweden (2006b) Registerbaserad arbetsmarknadsstatistik 2004. AM0207.

Statistics Sweden (2007a) Sysselsättningen i kommuner och län 2006. AM 32 SM 0702.

Statistics Sweden (2007b) AKU Grundtabeller år 2006, AM102 Grundtabeller.

Statistics Sweden (2008) Förvärvsarbetande (dagbefolkning) efter yrkesställning 2003, URL (consulted December, 2008):

http://www.scb.se/Pages/TableAndChart__158581.aspx.

Thurik, R.A., Carree, M. A., van Stel, A.J. and Audretsch, D.B. (2008) 'Does Selfemployment Reduce Unemployment?', Journal of Business Venturing 23(6): 673686.

van Stel, A.J. (2003) 'COMPENDIA 2000.2: A Harmonized Data Set of Business Ownership Rates in 23 OECD Countries', EIM Research Report H200302. Zoetermeer: EIM.

van Stel, A.J. (2005) 'COMPENDIA: Harmonizing Business Ownership Data Across Countries and Over Time', International Entrepreneurship and Management Journal 1(1): 105-123.

van Stel, A.J. (2008) 'The COMPENDIA Database: COMParative Entrepreneurship Data for International Analysis", in Congregado, E. (ed.) Measuring Entrepreneurship, 65-84. New York: Springer.

van Stel, A.J and Carree, M.A. (2004) 'Business Ownership and Sectoral Growth. An Empirical Analysis of 21 OECD Countries' International Small Business Journal 22(4): 389-419. 